\title{
Coastal Ecosystem as Salt Production Centre in Indonesia
}

\author{
M. Zaki Mahasin*, Yety Rochwulaningsih, and Singgih Tri Sulistiyono \\ Department of History, Faculty of Humanities, Diponegoro University, Indonesia
}

\begin{abstract}
This study analyzes several factors in which salt production can be produced and also identify the existing knowledge to manage the process as well as equipment of salt making. This study is qualitative research, therefore primary and secondary data of climatology, land typology and land use have been used. The results of this study show there are some factors that affected salt production, including rainfall, soil texture, land contour; and access to seawater. The rainfall is a major factor affecting the success of salt making in Indonesia. Meanwhile, heavy rain has influenced the success of salt production. Soil texture plays an important role in salt production. It is not only due to the effect on the productivity and quality of the water above it but also because of its suitability for the construction of salt ponds and embankment. Seawater access to is also greatly crucial in salt production. Ideal access to seawater is by utilizing tides so that it does not need a machine to pump seawater to the salt production plots.
\end{abstract}

Keywords: Coastal Ecosystem; Salt Production Centre.

\section{Introduction}

Indonesia as a maritime country has very potential marine and coastal resources, consisting of 17,508 islands with a coastline of $81,000 \mathrm{~km}$ as the second longest in the world after Canada. Therefore, of the objective conditions as maritime nation, it is appropriate that the concept of maritime world development along with coastal communities and small islands be placed in a central position with a clear alignment of each policy taken by the government [1]. A very contradictory condition actually occurred in the new order period in which even though the Indonesian government in 1974 made a marine development policy called "blue revolution", but the new policy resulted to an action program limited to the motorization of ships and fishing gear that began with the assistance of Purseine ships and Longline ships for tuna in the waters of the Indian Ocean Exclusive Economic Zone (EEZ) [2]. As for the salt sector, which is an integral part of the maritime economy, there is no policy in favor of the interests of business actors, especially in the upstream part - salt farmers as producers of raw

*Corresponding author: zaki_dkp@yahoo.com 
salt. There is a policy related to iodized salt and salt import, which actually causes marginalization of the people's salt business [3].

Salt production in Indonesia is generally carried out by the method of seawater evaporation. This method is applied by considering the geographical and climatic conditions in Indonesia. Therefore, only certain Indonesia's coastal areas have the potential to become salt production land. Some of the main factors affecting an area that can be used as salt production land include rainfall, soil texture, soil contour, and access to seawater sources.

In general, salt production models in Indonesia use evaporation, which is evaporation of seawater in shallow ponds by taking into account the thickness of seawater in these ponds. This has been applied since the Dutch occupation era on salt commodity in Madura in the production process emphasizing the method of evaporation in shallow ponds to accelerate the evaporation process [4].

Study of coastal area as a salt production land in Indonesia, uses several relevant scientific works to the research problem as a literature review. This literature review is important, because it is useful for; (1) clarifying the root of problem under study, (2) helping sort out research procedures, (3) deepening the theoretical basis related to the research problem, (4) critically examining the advantages and disadvantages of previous similar research results, (5) avoiding duplication research [5].

This research was conducted using a literature review of the scientific work of several experts related to the salt production methods in Indonesia and the factors affecting it. Rainfall is a major factor affecting salt production in Indonesia. Land to be used for salt production must be in an area with no more than $60 \mathrm{~mm}$ of rainfall per month. The average amount of rainfall in Indonesia in a year ranges from $500 \mathrm{~mm}$ to more than 5,000 $\mathrm{mm}$. This rainfall is also affected by the location and height of a place, i.e. places located on the west or south coast that directly face the west wind have great rainfall.

\section{Indonesia's Rain and Soil Conditions}

There are several areas with very low rainfall and several areas with high rainfall. (1) Areas that receive an average annual rainfall of less than $1,000 \mathrm{~mm}$, covering $0.6 \%$ of the total area of Indonesia, including Nusa Tenggara, and 2 regions in Sulawesi (Palu and Luwuk valleys); (2) The areas receiving rainfall between 1,000-2,000 $\mathrm{mm}$ annually including some of Nusa Tenggara, the narrow areas of Merauke, Aru Islands, and Tanibar; (3) The areas receive rainfall between 2,000-3,000 $\mathrm{mm}$ annually, including East Sumatra, South and East Kalimantan, most of West Java and Central Java, some of Irian Jaya, Maluku Islands, and most of Sulawesi; (4) Areas with the highest rainfall of more than 3,000 mm annually including the highlands in West Sumatra, Central Kalimantan, the central Irian highlands, and several regions in Java, Bali, Lombok, and Sumba. The most rainfall in Indonesia is in Baturaden, Central Java, reaching 7,069 mm/year while Palu in Central Sulawesi is the driest area with rainfall of around $547 \mathrm{~mm} /$ year [6].

Some factors affecting the process of rain in the territory of Indonesia, are including: the position of latitude, wind patterns (trade winds and monsoons), the presence of oceans and other water levels, as well as mountains and high mountains. From the effect of these physical factors, there are at least 3 types of rainfall patterns that occur in the territory of Indonesia, namely the equatorial, monsoon, and local types [7].

Equatorial type, this pattern is related to the movement of convergence zone to the north and south following the apparent pseudo sun movement, characterized by twice of the maximum monthly rainfall in a year. Bimodal type of rainfall (two peaks of rain) that usually occurs around March and October or during the equinox. The regions of Indonesia that follow this pattern are some areas of Sumatra and Kalimantan.

Monsoonal type, Monsoonal pattern is affected by sea winds on a very broad scale. This 
kind of rain is characterized by a clear difference between the period of rainy season and dry season in a year, and the maximum monthly rainfall in a year only occurs once. Monsoon is characterized by a type of rainfall that is unimodal (one peak of the rainy season) where in June, July and August there is a dry season, while for December, January and February are wet months. While the remaining six months are a transition period. The distribution of this type of rainfall is on the islands of Java, Bali, and Nusa Tenggara

Local Type, this rainfall patterns are characterized by the magnitude of local physical environmental condition effects, for example waterways or oceans, high mountains, and intensive local warming. The local pattern occurs only once in the maximum monthly rainfall in a year, and there are several dry months which coincide with the blowing of the West Monsoon wind characterized by the shape of unimodal rain pattern (one peak of rain), but the shape is opposite to the type of monsoon rain (please see Figure 1). The distribution includes Papua, Maluku, and some of Sulawesi [8].

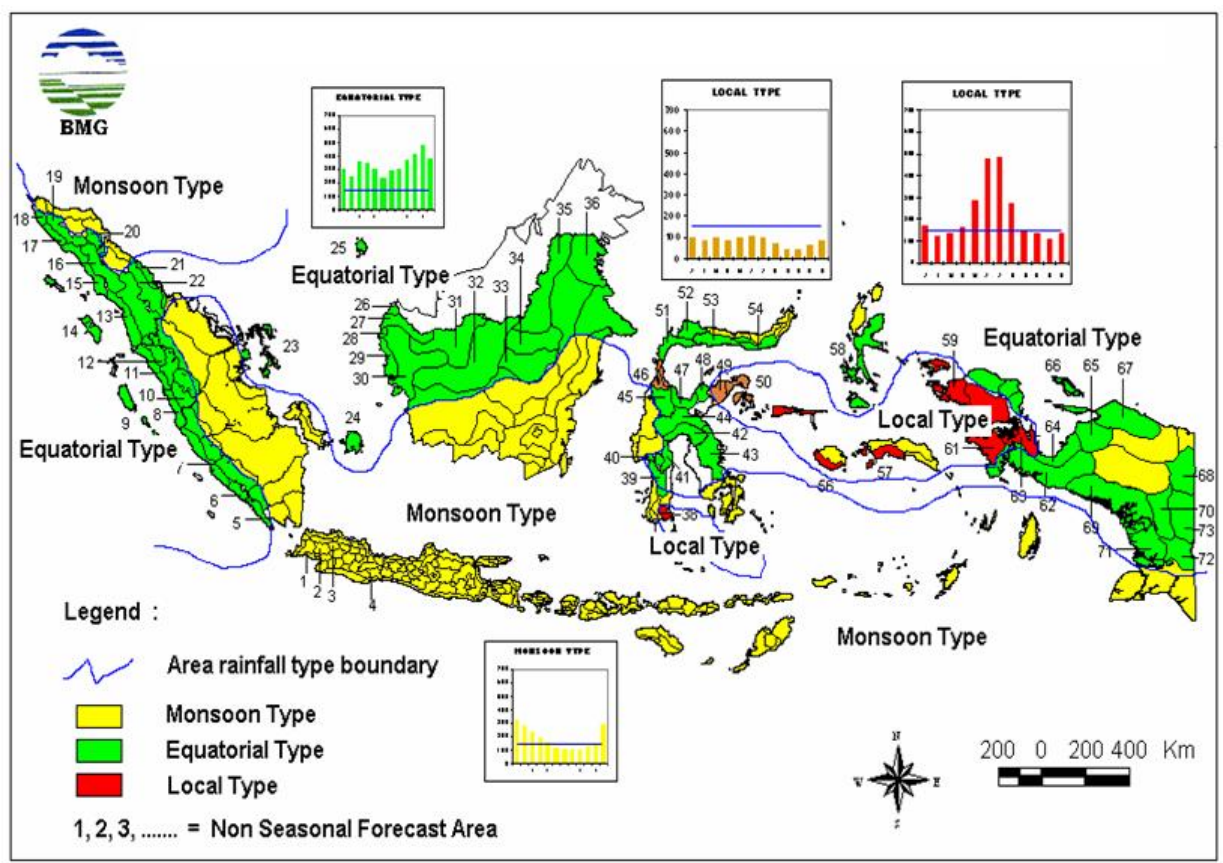

Figure 1. Indonesian Monsoon Condition [16]

Soil texture factors also greatly affect salt production in Indonesia. Land with a dominant texture of sand will be difficult to use for salt production due to high porosity. Likewise, soil texture with clay dominance will not fit for salt production. Combination of the two is needed to produce salt production in a suitable land for salt production, as salt land in Madura island which has long been used as a national salt land. This salt land has existed since the Dutch occupation era until now. This is because the texture is suitable for salt production.

Soil texture in Madura island in general consists of the Red Mediterranean Complex and Litosol which are made from the main Limestone and Sandstone. The Red Mediterranean and Litosol lands in Madura develop in dry climatic conditions. Soil with limestone parent material has a higher soil $\mathrm{pH}$ value than that derived from sandstone parent; this is due to the low leaching of bases, especially if the soil has a fine texture. The main problem with this type of soil is the availability of water and the high $\mathrm{pH}$ of the soil which is frequently above 7 (soil reactions tend to be alkaline). Alkaline-tended soil reactions will raise problems directly for suitability of plants and nutrient availability, which is the low availability of 
micro elements as well as phosphates because they are bound by $\mathrm{Ca}^{2+}$. Furthermore the other main important lands are the Mediterranean Complex, Grumusol, Regosol, and Litosol. This soil is characterized by wide cracks in the dry season due to shrinking of clay soil, and heavy tillage in the rainy season. These soils have a high clay content. With good management, it can be directed towards high soil productivity. The content of organic substance and nitrogen is very low. Therefore, the management of both soils is a major concern. This physical and chemical problem becomes the main problem in the management of these soils [9].

According to Tonggiroh (2019), alluvial soil originates from clay deposits that are commonly found along river basins[10]. The parent material comes from colluvium and alluvium, grayish brown, clay texture and solid structure, firm consistency in damp and plastic when wet and hard when dry. Good soil for salt ponds is sandy clay or muddy clay which is generally formed from sediment (alluvial) (Afrianto and Liviawaty 1991) [11].

Soil consists of minerals and organic materials of various sizes. The minerals are found in soil particles in the form of clay, silt, silt, and sand, while organic matter is present in various processes in water. The land used for the location of the pond is determined in tidal areas. Altitude of the whole place should not exceed the height of the highest tide and should not be less (lower) than the lowest tide [12].

The factor affecting salt production in coastal areas is the land contour. This is important to note because this contour will determine the management of seawater which is the raw material for salt production. According to Purbani [13], salt ponds are desirable for small ramps or slopes because they are used to facilitate water flow and minimize construction costs. In constructing a pond, the height must be adjusted to the tidal difference. Tides need to be considered by looking at the condition of land contour including its slope. The principle of salt production with this evaporation method must be performed on sloping land so that water can flow but the evaporation process continues.

Tambunan et al. [12] studies that the suitable slope of the salt ponds in Juwana Pati was $0.56 \%-1.3 \%$. This was intended to maintain the evaporation process and the flow of seawater from one evaporation pond to another.The next factor affecting salt production in coastal areas is access to raw materials for seawater. This access determines the quality of seawater obtained and the cost of salt production. The factor of seawater access as a supply of raw materials is the direct costs in salt business activities [14].

\section{Results}

Salt production in Indonesia's coastal areas has several requirements that must be met. This does not mean that all Indonesian coastal areas can be used for salt production. These requirements are: a) rainfall; b) soil texture; c) land contour; and d) access to seawater. If the four factors are not met, salt production cannot be performed or at least it is difficult to produce salt with the desired productivity, quality, and production costs.

Required rainfall in coastal areas shall not exceed $60 \mathrm{~mm}$ monthly in the dry season. Such rainfall is not found in all coastal areas of Indonesia. Rainfall patterns should not occur twice in a year as in equatorial areas, such as Sumatra and Kalimantan. As known, in the two big islands, so far no salt production has been found with the evaporation system as it operates in Java, Madura, and Nusa Tenggara in general, which has a type of monsoonal rainfall. This is because during the dry season, Sumatra and Kalimantan still have high rainfall, likewise, as happens in coastal areas that have local rainfall patterns that are affected by local landscapes, such as mountains. Such rainfall patterns occur in Maluku and Papua. In both islands, salt production cannot be performed with an evaporation system. 
Soil texture plays an important role in the salt production. It is not only due to the effect on the productivity and quality of the water above it, but also because of its suitability for the construction of salt ponds and embankment. Texture is a comparison between sand, dust, and clay fractions, that is, soil particles of which the effective diameter is less than or equal to 2 $\mathrm{mm}$. In the analysis, the organic substance fractions texture are not taken into account. Soils with various sand, dust, and clay comparisons are classified into various texture classes as illustrated in the texture triangle below [15].

This texture triangle shows that the composition of sand, clay, and dust will always be bound in a soil texture. In general, suitable soil texture for salt production land is sandy clay loam with composition as in the triangle above, which contains $50 \%$ of sand, $20 \%$ of dust, and $30 \%$ of clay.

The choice of soil texture is very important to obtain optimal salt production. Such soil texture is abundant in the north coast of Java and Madura. It is unlike the southern coast of Java, which has more sand content so that it cannot be used as a salt production area due to the dominant nature of porous sand.

Soil contour in this case is the slope of the land used as salt ponds. The ideal slope in salt plots is no more than $2 \%$. This land slope serves to slowly flow seawater to the next plots while still optimizing the process of seawater evaporation before entering into the crystallization plot. This soil contour can be formed when entering the salt production season, that is before the dry season. Salt plots are formed according to their proportions, including the initial seawater ponds, then evaporation plots which are divided into several plots, and finally crystallization plots/tables. This land contour is important in addition to managing seawater through the removal of seawater by gravity that is minimizing production costs. On land with rock contours, the salt production will be difficult as the case in some small islands and the southern coast of Java.

Seawater access to land is also greatly crucial in salt production. Ideal access to seawater is by utilizing tides so that it does not need a machine to pump seawater to the salt production plots. The farther the distance from the source of seawater, the higher costs will be incurred. Likewise, when seawater source is from the seawater path, it further decreases its salinity and can no longer be used for salt production. This saltiness is an indicator of the presence of sodium chloride or salt.

Salt production is difficult to do in coastal areas that have steep cliffs, such as on the southern coast of Gunungkidul Regency. Although the seawater source in the area is good because of the low level of sea pollution, the production of salt by the evaporation method cannot be carried out due to the difficulty of access to seawater.

\section{Conclusion}

Indonesia which has a long coastal area does not guarantee that it can be used for salt production. In general, salt production in Indonesia uses the evaporation method because it is considered easy and does not require expensive production costs. However, salt production in coastal areas with this evaporation method must meet several aspects, namely a) rainfall; b) soil texture; c) land contour; and d) access to seawater.

These aspects must be met simultaneously and not partially. If the four aspects are not met simultaneously, salt production will not be optimal. Therefore, the purpose of salt business to obtain high productivity and quality results along with efficient production costs will not be achieved. 


\section{Acknowledgements}

This publication is funded by Directorate Research and Community Services, Minsitry of Education and Culture, under the schene of Research Dictoral Dissertation (225-09/UN7.6.1/PP2020).

\section{References}

1. Rokhmin Dahuri, New Paradigm for Maritime-Based Development in Indonesia (Scientific Oration of Coastal and Marine Resource Management Professor, Faculty of Fisheries and Marine Sciences, Bogor Agricultural University, 2003).

2. Yety Rochwulaningsih, Singgih Tri S., Noor Naelil M., Nazala Noor M., "Marine Policy Basis of Indonesia as a Maritime State: The Importance of Integrated Economy" in Journal of Marine Policy, Vol. 108, 2019, 103602.

3. Yety Rochwulaningsih, Marjinalisasi Garam Rakyat (Semarang: Madina Semarang, 2012), p. 9.

4. Ibrahim Alenezi, Salinity Gradient Solar Ponds: Theoretical Modelling and Integration with Desalination. (Thesis University of Surrey, 2012).

5. W. B. Castetter, and R. S. Heisler. Developing and Defending A Disertation Proposal (Pennsylvania: Graduate School of Education, University of Pennsylvania, Philadelphia, 1984), p. 38-43.

6. http://klastik.wordpress.com/2006/12/03/pola-umum-curah-hujan-di-indonesia.

7. Tukidi 2010. Rainfall Character in Indonesia. Department of Geography, FIS UNNES, volume 7 No. July 2, 2010.

8. Eddy Hermawan. Classification of Rainfall Patterns That Occur in Some Areas of Sumatra Island Based on The Results of Spectral Technique Analysis. Journal of Meteorology and Geophysics, 11, 2 (2010).

9. Slamet Supriyadi, Soil Fertility of Dry Land in Madura. Journal of Embryo, 4, 2 (2007).

10. Adi Tonggiroh, Basics of Geochemical Exploration. Social Politic Genius (SIGn). Makassar. (2019)

11. E. Afrianto and E. Liviawaty. Fish Curing and Processing (Kanisius, Yogyakarta, 1991).

12. R. B. Tambunan, Hariyadi, Adi Santoso. 2012. Evaluation of Salt Pond Conformity in Terms of Physical Aspects in Sub-District of Juwana, Pati Regency. Journal of Marine Research, 1, 2 (2012).

13. Purbani, Handbook for Making Quality Salt (Maritime and Fisheries Research Agency of the Ministry of Maritime Affairs and Fisheries, 2003).

14. H. T. El-Dessouky, H.M. Ettouney Fundamentals of Salt Desalination (Elsevier Science. Amsterdam, 2002).

15. F. Agus, Yusrial and Sutono, Determination of Soil Texture. Indonesian Center for Agricultural Land Resources. Agriculture Departement, (2006)

16. Indonesian Meteorology, Climatology, and Geophysical Agency, (2019) 